\title{
Effects of zearalenone in prepubertal gilts ${ }^{1}$
}

\author{
Letícia C. Teixeira $^{2 *}$, Fabiano Montiani-Ferreira² ${ }^{2}$, Rosângela Locatelli-Dittrich², \\ Elizabeth Santin ${ }^{2}$ and Geraldo C. Alberton ${ }^{2 *}$
}

\begin{abstract}
Teixeira L.C., Montiani-Ferreira F., Locatelli-Dittrich R., Santin E. \& Alberton G.C. 2011. Effects of zearalenone in prepubertal gilts. Pesquisa Veterinária Brasileira 31(8):656-662. Programa de Pós-Graduação em Ciências Veterinárias, Setor de Ciências Agrárias, Universidade Federal de Paraná, Rua dos Funcionários 1540, Bairro Cabral, Curitiba, PR 80035-050, Brazil. E-mail: leticia.cteixeira@yahoo.com.br

Prepubertal gilts were fed with a diet containing zearalenone (ZEA) in a concentration of $0.75 \mathrm{mg} / \mathrm{kg}$ for 21 days. The effects of this mycotoxin on morphologic aspects of the reproductive tract as well as on complete blood count (CBC), serum biochemistry analysis (SBA) and humoral immune response against sheep red blood cells (SRBC) were evaluated. There was a significant increase $(P<0.05)$ on the reproductive tract weight, vulvar area, height of the epithelial cells of endometrial glands and uterine mucosa. These results showed the ability of this nonsteroidal mycotoxin in mimicking actions of $17 \beta$ estradiol at the concentration of $0.75 \mathrm{mg} / \mathrm{kg}$. No changes in weight gain, CBC, SBA parameters and humoral response against SRBC were observed.
\end{abstract}

INDEX TERMS: Swine, zearalenone, mycotoxin, uterus, vagina, humoral immune response.

RESUMO.- [Efeitos da zearalenona em leitoas prépúberes.] Leitoas pré-púbere foram alimentadas com ração contendo $0,75 \mathrm{mg} / \mathrm{kg}$ de zearalenona (ZEA) durante 21 dias. Os efeitos da micotoxina foram avaliados nos aspectos morfológicos do trato reprodutivo, bem como na hematologia, bioquímica séricas e resposta imune humoral contra hemácias de carneiro. Foi observado aumento significativo $(\mathrm{P}<0,05)$ no peso de trato reprodutivo, na área vulvar, na altura das células epiteliais das glândulas endometriais e superficiais da mucosa uterina. Estes resultados demonstraram a capacidade desta micotoxina não esteróide em mimetizar as ações do $17 \beta$ estradiol na concentração de $0,75 \mathrm{mg} / \mathrm{kg}$. Entretanto, apesar das evidentes alterações nos parâmetros estudados no trato reprodutivo, não foram observadas alterações no ganho de peso, bem como nas avaliações hematológicas e bioquímicas sangüíneas e na resposta imune humoral contra hemácias de carneiro.

TERMOS DE INDEXAÇÃO: Suínos, zearalenona, micotoxina, útero, vagina, resposta imune humoral.

\section{INTRODUCTION}

Corn is highly susceptible to contamination by Fusarium

\footnotetext{
${ }^{1}$ Received on February 2, 2011.

Accepted for publication on March 31, 2011.

2 Programa de Pós-Graduação em Ciências Veterinárias, Setor de Ciências Agrárias, Universiade Federal do Paraná, Rua dos Funcionários 1540, Bairro Cabral, Curitiba, PR 80.035-050, Brazil. *Corresponding author: leticia.cteixeira@yahoo.com.br
}

spp. fungi that can produce many mycotoxins (Kumar et al. 2008). Zearalenone (ZEA) stands out among these by its frequent occurrence in southern Brazil (Salay \& Mercadante 2002), where high temperature variations provide necessary conditions for mycotoxin production (Martins \& Martins 2002). ZEA is a nonsteroidal mycotoxin with estrogenic effects, which can cause reproductive disorders. Pigs are particularly exposed to ZEA by having their diet usually consisting of corn and by being particularly sensitive to its toxic effects (Malekinejad et al. 2006). Comparing to other species, pigs are especially sensitive to ZEA intoxication because the hepatic biotransformation of this mycotoxin results in a higher production of $\alpha$-zearalenol in this species, which is even more toxic metabolite than ZEA (Kuiper-Goodman et al. 1987, Fink-Gremmels \& Malekinejad 2007). Additionally, the $\alpha$-zearalenol has a higher affinity to bind to estrogen receptors when compared to ZEA and the other metabolite $\beta$-zearalenol (Olsen et al. 1981, Malekinejad et al. 2006).

The clinical scenario of intoxication by ZEA varies according to the amount of toxins ingested, period of ingestion, gender, and reproductive stage of each patient. The signs can often be confused with a number of other diseases or management problems. However, vulvar edema and hyperemia are classic signs of this type of intoxication by ZEA (Mostrom et al. 2007).

Most studies of experimental intoxication with ZEA use dosages exceeding $1 \mathrm{mg} / \mathrm{kg}$ (Etienne \& Jemmali 1982, Speranda et al. 2006, Andretta et al. 2008). Doll et al. (2004), 
however, found that pathologic changes started to appear at doses as low as $0.42 \mathrm{mg} / \mathrm{kg}$. Additionally, it is known that the occurrence of clinical signs depends on individual factors, dosage, and its clinical manifestation is conditioned to previous stress suffered by exposed animals (Smith et al. 2005). Under experimental conditions, due to greater control of stress factors, proper management, and low challenge, mainly related to infectious pressure; clinical signs were not evident, especially when using very low concentrations of ZEA. This study aimed to evaluate the effects of ZEA in the diet of prepubertal gilts, in a controlled environment. Thus, for the present study, a ZEA concentration of $0.75 \mathrm{mg} / \mathrm{kg}$ was chosen, which was thought to be high enough to cause pathologic changes and relatively close to concentrations routinely reported in the field as capable of causing intoxication (Vargas et al. 2001, Doll et al. 2004). The toxic effects produced were evaluated using a comparison of reproductive, hematological and biochemical parameters, weight gain of the animals, and humoral immune response against sheep red blood cells (SRBC).

\section{MATERIALS AND METHODS}

Animals. Twelve 32-day-old gilts were used on the experiment. General health status of the animals was verified by clinical, hematological, and biochemical blood test. All gilts were from Danbred ${ }^{\circledR}$ line, with an average weight of $8.55 \pm 0.60 \mathrm{~kg}$ on the first day of the experiment. The investigation was conducted in 21 days. The animals had one week of housing and management adaptation before the experimental phase. For the experiment, the population was divided into two groups of six animals that received two distinct treatments: T1 (control diet) and T2 (experimental diet with $0.75 \mathrm{mg} / \mathrm{kg}$ of ZEA). They were housed in individual stalls of plastic floor ( $2 \mathrm{~m}$ length $\mathrm{x} 1 \mathrm{~m}$ width).

Table 1. Bromatological composition of the basic diet fed to the gilts.

\begin{tabular}{lc}
\hline \multicolumn{1}{c}{ Nutrients } & Quantity \\
\hline Humidity (\%) & 10.212 \\
Crude Protein (\%) & 20.172 \\
Crude Fat (\%) & 4.513 \\
Ash (\%) & 6.711 \\
Crude Fiber (\%) & 3.279 \\
Calcium (\%) & 0.693 \\
Available phosphorus (\%) & 0.449 \\
Lysine (\%) & 1.287 \\
ME kcal/kg & $3,284.39$ \\
\hline
\end{tabular}

ME = Calculated metabolizable energy.

Diet, feeding and weekly management. The diet of the gilts was composed of corn, soybeans, and vitamin-mineral nucleus formulated according to NRC (NRC, 1998), consistent with the phase of the life cycle (Table 1). The corn used for diet preparation was obtained from a supplier who did not perform careful selection of it.

Gilts were monitored twice a day and were weighed every week, obtaining the calculated weight gain. Vulvar measurements (millimeters) were performed weekly with digital calipers. The vulvar area was obtained by multiplying the width (latero-lateral axis, of the vulvar labia majora) and height (dorsal-ventral axis, from dorsal commissure to prepuce of clitoris) measurements of the vulva.

Addition of zearalenone and mycotoxin analysis. The ZEA (Sigma Aldrich Corporation) had 99\% minimum purity and was initially mixed in degerminated corn in the process of serial dilution. A mixture of degerminated corn meal + ZEA was incorporated into the diet with a "Y" type mixer. Samples of corn and soybean meal used to produce the diet as well as final feed samples were sent for mycotoxicological analysis at the Laboratory of Mycotoxins (LABMIC) at the Department of Agribusiness, Food and Nutrition ESALQ/USP being analyzed by thin layer chromatography. The concentration of ZEA and ochratoxin were determined by the modified method of Soares and Rodriguez-Amaya (1989) with immunoaffinity column purification. The concentration of aflatoxins B1, B2, G1, G2 were determined by the MAPA method (Ministry of Agriculture and Livestock) Brazil (2000). The correction of calculation was performed to obtain the final concentration of ZEA at $0.75 \mathrm{mg} / \mathrm{kg}$. After mixing and preparation of the final diets, samples of each treatment were also analyzed for the same toxins by the same methods. Food and water were provided to animals ad libitum.

Hematological and biochemical analysis. Blood samples were collected at the first and last day of the experiment. Samples were obtained by puncturing the vena cava with $18 \mathrm{G}$ needle adapted to a $20 \mathrm{~mL}$ syringe. The blood was immediately transferred to tubes with and without EDTA. The blood without EDTA was centrifuged to obtain serum. Serum samples were stored at $-20^{\circ} \mathrm{C}$ until analysis. The enzymes aspartate aminotransferase (AST) and gammaglutamil transferase (GGT) were determined by kinetic method; urea; and total protein (TP) by biuret method; and albumin by bromocresol green reaction. Analyses were performed on semi-automatic biochemical analyzer CELM-SBA-200.

Blood samples with EDTA were processed to obtain hematological parameters. Blood smears were made immediately after the collection. Total number of leukocytes and erythrocytes and hemoglobin concentration $(\mathrm{Hb})$ were obtained in the automatic cell counter CELM-CC-530. The packed cell volume (PCV) was determined using a hematocrit centrifuge at $10.000 \mathrm{x} g$ for 5 minutes. The calculated erythrocyte indices of mean corpuscular volume (MCV), and mean corpuscular hemoglobin concentration (MCHC) were obtained by Wintrobe formula (MCV = Ht x 10/ erythrocyte; $\mathrm{MCHC}=\mathrm{Hb} \times 100 / \mathrm{Ht}$ ). Total plasma protein (TPP) values were obtained by refractometry. Leukocyte differential counts were made on blood films stained with Wright's stain, using average of 100 leukocytes.

Morphologic and histopathologic analysis of organs. The animals were slaughtered after being fed with the experimental diets for 21 days in a commercial abattoir. Liver, mesenteric lymph nodes, and reproductive tract including ovaries, uterus, vagina and vulva were examined macroscopically, evaluating general appearance. Reproductive tract were photographed, dissected and weighed. Then, vulva were removed and ovaries, uterus and vagina were weighted together. The relative weight of the reproductive tract and the ovaries-uterus-vagina complex were calculated, dividing the values of the observed weights by the body weight and multiplying by 100 .

Samples of uterus, lymph nodes, and liver were collected and fixed in $10 \%$ buffered formalin phosphate, shortly after slaughter. Then samples were processed according to routine histologic techniques, embedded in paraffin and cut to obtain sections of 5 ìm thickness. The sections were fixed on glass slides and stained with hematoxylin and eosin.

Samples of liver, lymph nodes, uterus and vagina were evaluated for the presence of morphologic changes. Three sections of each uterine horn, collected at mid portion were measured following these criteria: mean height of epithelial cells of the endometrial glands and mean height of epithelial cell of the uterine mucosa surface. These measurements were used as markers for cellular hypertrophy (Heneweer et al. 2007). For this measurement, three 
microscopic fields with endometrial glands and three with the epithelial surface layer of the uterine mucosa were photographed with a magnification of 400x, measuring four times in different fields, with the program "Motic Images Plus $2.0^{\circledR}$ ". The vaginal canal histopathologic analysis was performed with fragments from two locations, one from the proximal third of the uterus and other from the distal third, closest to the vulva, due to normal differences in stratification of the epithelium in length, with a reduction of stratification as it approaches the cervix.

Evaluation of humoral immune response against sheep red blood cell. The humoral immune response was measured by determining anti-sheep red blood cell plate hemagglutination test following the protocol with two intramuscular inoculations of $10^{8}$ SRBC diluted in saline and with Freund's complete adjuvant (modified from Bonnette et al. 1990). The first inoculation was made on the $10^{\text {th }}$ day after the beginning of the experiment and the second inoculation seven days after the first inoculation $\left(17^{\text {th }}\right.$ day of the experiment). Blood samples were collected five days after the first inoculation and four days after the second inoculation. Serum was kept frozen at $-20^{\circ} \mathrm{C}$ in polyethylene tubes for plate hemagglutination test (HA). The hemagglutination titers were determined after inactivation of the serum by serial dilution method according to Schurig et al. (1978).

Statistical analysis. The experimental design was completely randomized with two treatments and six replicates. Each animal was considered as an experimental unit. The results of serological analysis for humoral response against SRBC were converted to $\log _{10}$ before statistical analysis. Numeric continuous data between groups were evaluated statistically by one-way ANOVA. When the effect of treatment was detected, a Tukey-Kramer post-hoc test was performed to identify significant differences between means. Differences were deemed significant when $\mathrm{P}<0.05$ (SAS-JMP, version 3.2.2; SAS Institute Inc, Cary, NC).

\section{RESULTS}

\section{Mycotoxicological analysis}

Mycotoxicological results are shown in Table 2. ZEA was previously present in milled corn, thus a correction was made to obtain a final concentration at T2 of $0.75 \mathrm{mg} / \mathrm{kg}$ of ZEA in the diet. A concentration of $0.335 \mathrm{mg} / \mathrm{kg}$ of ZEA was found in the control group. Traces of aflatoxin B1 $(0.014 \mathrm{mg} / \mathrm{kg})$ were detected in the milled corn, previously to final diet formulation. However, it was not detected after preparation of the diet.

\section{Vulva measurement and reproductive tract weight}

Significant differences of the vulva measurement were observed only in the $21^{\text {st }}$ day of experiment (Fig.1).

The weights of the reproductive tracts and ovaries-uterus-

Table 2. Mycotoxicological analysis results of diets with and without addition of ZEA and soybean meal and milled corn before preparing the feed

\begin{tabular}{ccccccc}
\hline PRODUCT & $\begin{array}{c}\text { ZEA } \\
(\mu \mathrm{g} / \mathrm{kg})\end{array}$ & $\begin{array}{c}\text { OCRA } \\
(\mu \mathrm{g} / \mathrm{kg})\end{array}$ & $\begin{array}{c}\text { AFB1 } \\
(\mu \mathrm{g} / \mathrm{kg})\end{array}$ & $\begin{array}{c}\mathrm{AFB} 2 \\
(\mu \mathrm{g} / \mathrm{kg})\end{array}$ & $\begin{array}{c}\mathrm{AFG1} \\
(\mu \mathrm{g} / \mathrm{kg})\end{array}$ & $\begin{array}{c}\mathrm{AFG} 2 \\
(\mu \mathrm{g} / \mathrm{kg})\end{array}$ \\
\hline T1 & 335 & $\mathrm{NP}$ & $\mathrm{NP}$ & $\mathrm{NP}$ & $\mathrm{NP}$ & $\mathrm{NP}$ \\
T2 & 753 & $\mathrm{NP}$ & $\mathrm{NP}$ & $\mathrm{NP}$ & $\mathrm{NP}$ & $\mathrm{NP}$ \\
Soybean meal & $<80$ & $\mathrm{ND}$ & $\mathrm{ND}$ & $\mathrm{ND}$ & $\mathrm{ND}$ & $\mathrm{ND}$ \\
Milled corn & 263 & $\mathrm{ND}$ & 1.4 & $\mathrm{ND}$ & $\mathrm{ND}$ & $\mathrm{ND}$
\end{tabular}

$\mathrm{ND}=$ not detected, $\mathrm{NP}=$ not performed, $\mathrm{ZEA}=$ zearalenone, $\mathrm{OCRA}=$ ochratoxin, $\mathrm{AF}=$ aflatoxin.

* Limit for detection/quantification of zearalenone $60.0-80.0 \mu \mathrm{g} / \mathrm{kg}$; ochratoxin $4 \mu \mathrm{g} / \mathrm{kg}$; aflatoxins $0.5-1.0 \mu \mathrm{g} / \mathrm{kg}$. vagina complexes of the group with ZEA (T2) were significantly higher than the control group (T1) (Fig.2).

\section{Epithelial cells height of the endometrial glands and uterine mucosa surface}

Results of height measurements of epithelial cells of endometrial glands and uterine mucosa surface are shown in

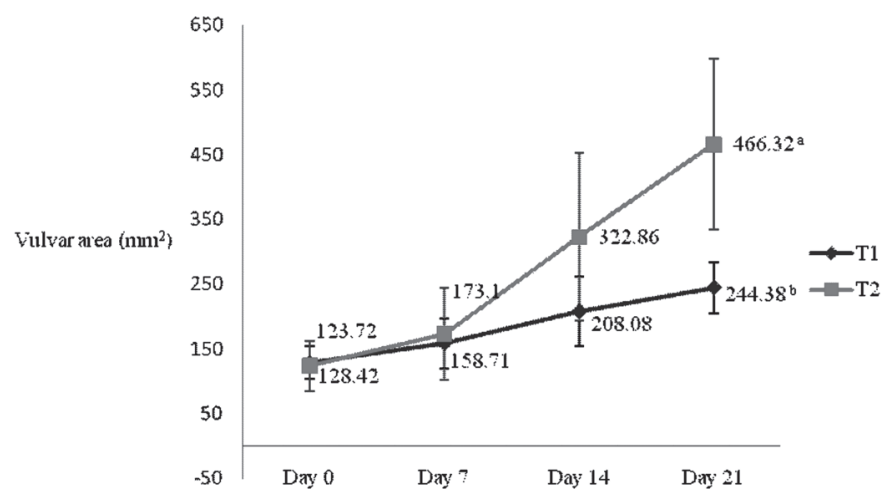

Fig.1. Evolution of the vulvar area (mean \pm standard deviation) for $\mathrm{T} 1$ (control) and T2 $(0.75 \mathrm{mg} / \mathrm{kg}$ zearalenone) during the experiment. Different letters differ statistically $(\mathrm{P}=0.018), \mathrm{T} 1$ (control) T2 $(0.75 \mathrm{mg} / \mathrm{kg} \mathrm{ZEA})$

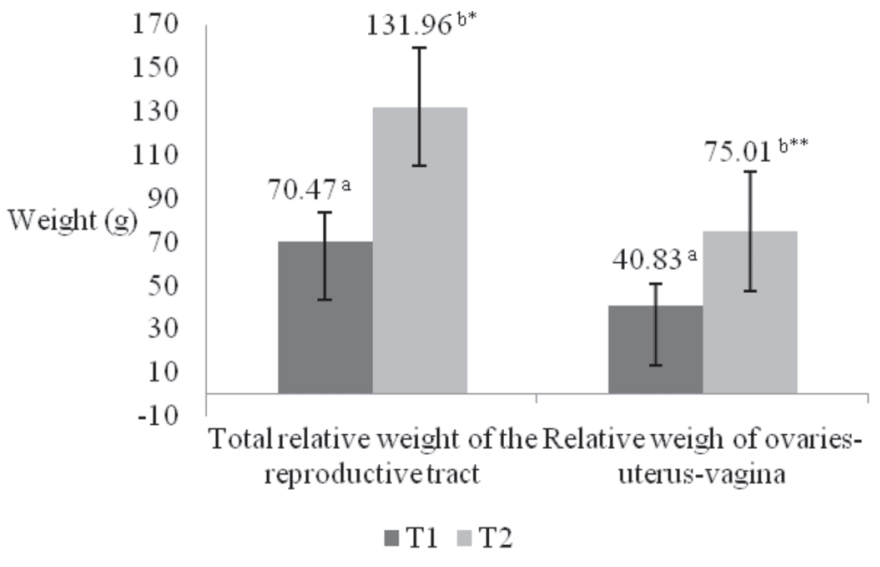

Fig.2. Mean $( \pm S D)$ of total relative weight of the reproductive tract and ovaries-uterus-vagina of T1 (control) and T2 $(0.75 \mathrm{mg} / \mathrm{kg}$ ZEA). Different letters differ statistically. ${ }^{*} \mathrm{P}=0.006,{ }^{* *} \mathrm{P}=0.016$.

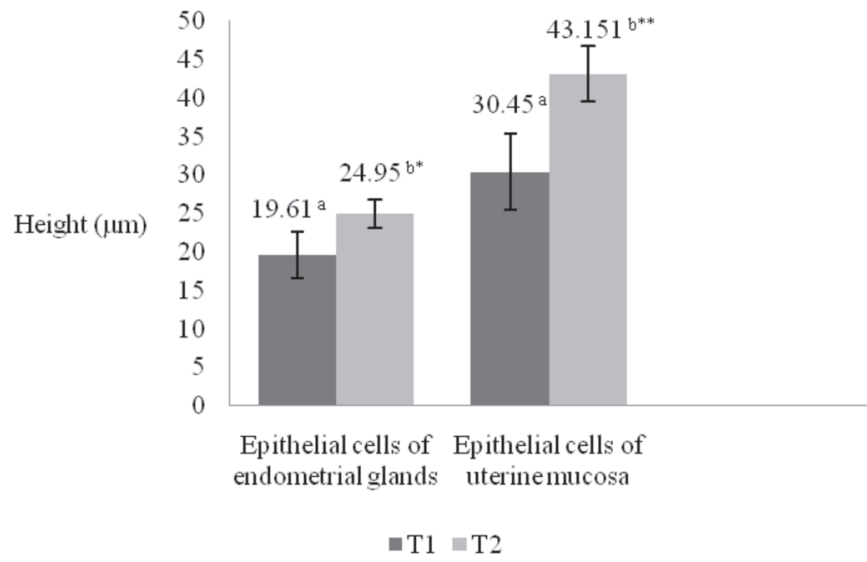

Fig.3. Mean $( \pm \mathrm{SD})$ of epithelial cells height of endometrial glands and uterine mucosa of T1 (control) and T2 $(0.75 \mathrm{mg} / \mathrm{kg}$ zearalenone). Different letters differ statistically. ${ }^{*} \mathrm{P}=0.0074 \mathrm{e}^{* *} \mathrm{P}=0.001$. 


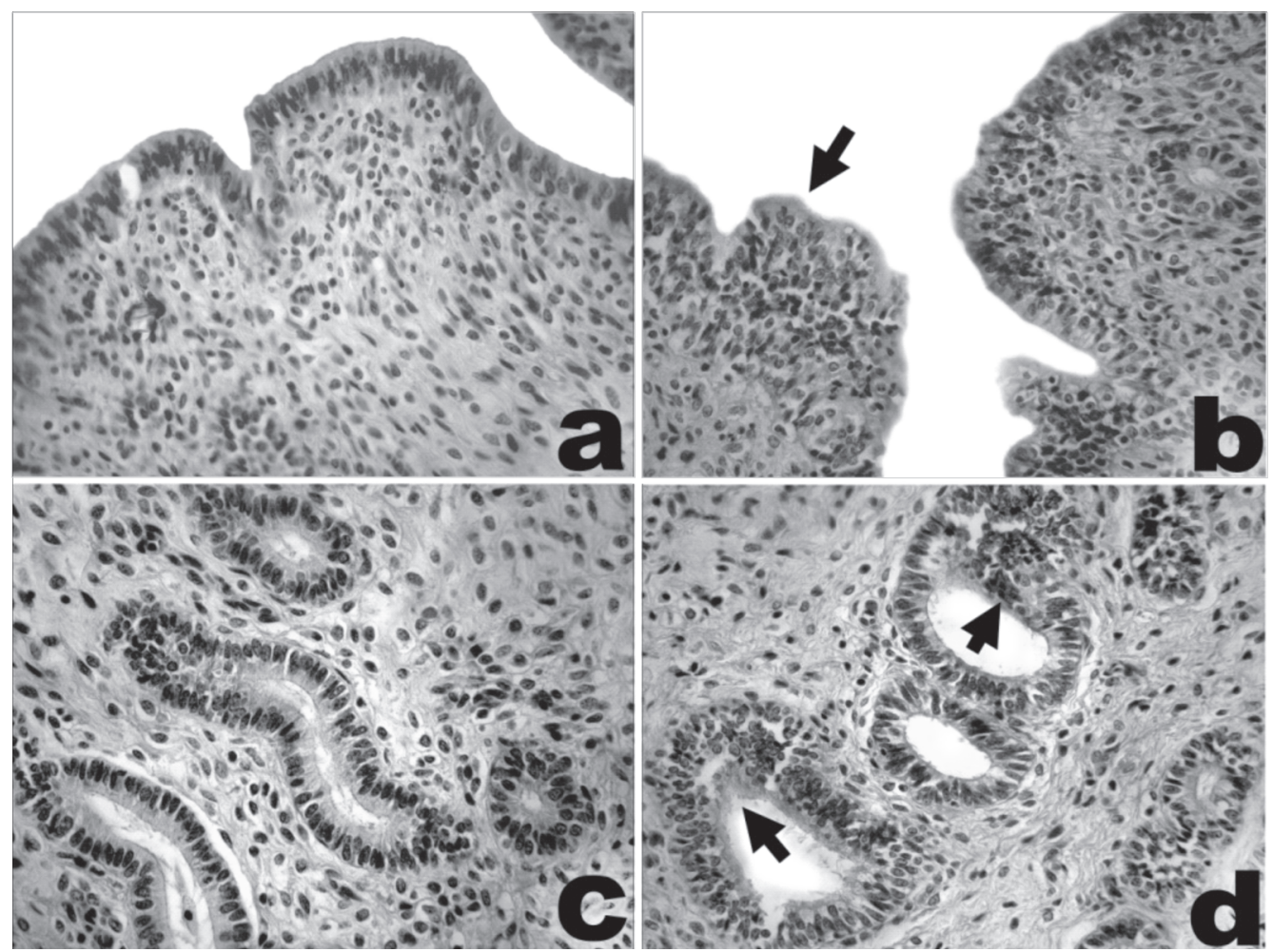

Fig.4. Uterus of gilts. HE, 400x, T1 (A and C, control) and T2 (B and D, 0.75mg/kg ZEA). (A) Regular epithelial layer of uterine mucosa. (C) Uniform and regular epithelial cells of endometrial glands. (B) Irregularity, thickening and proliferation of the uterine epithelial cells (arrow), squamous metaplasia of the uterus. (D) Hyperplasia of the endometrial glands (proliferation of epithelial cells with irregular increase of epithelial layers) (arrow).
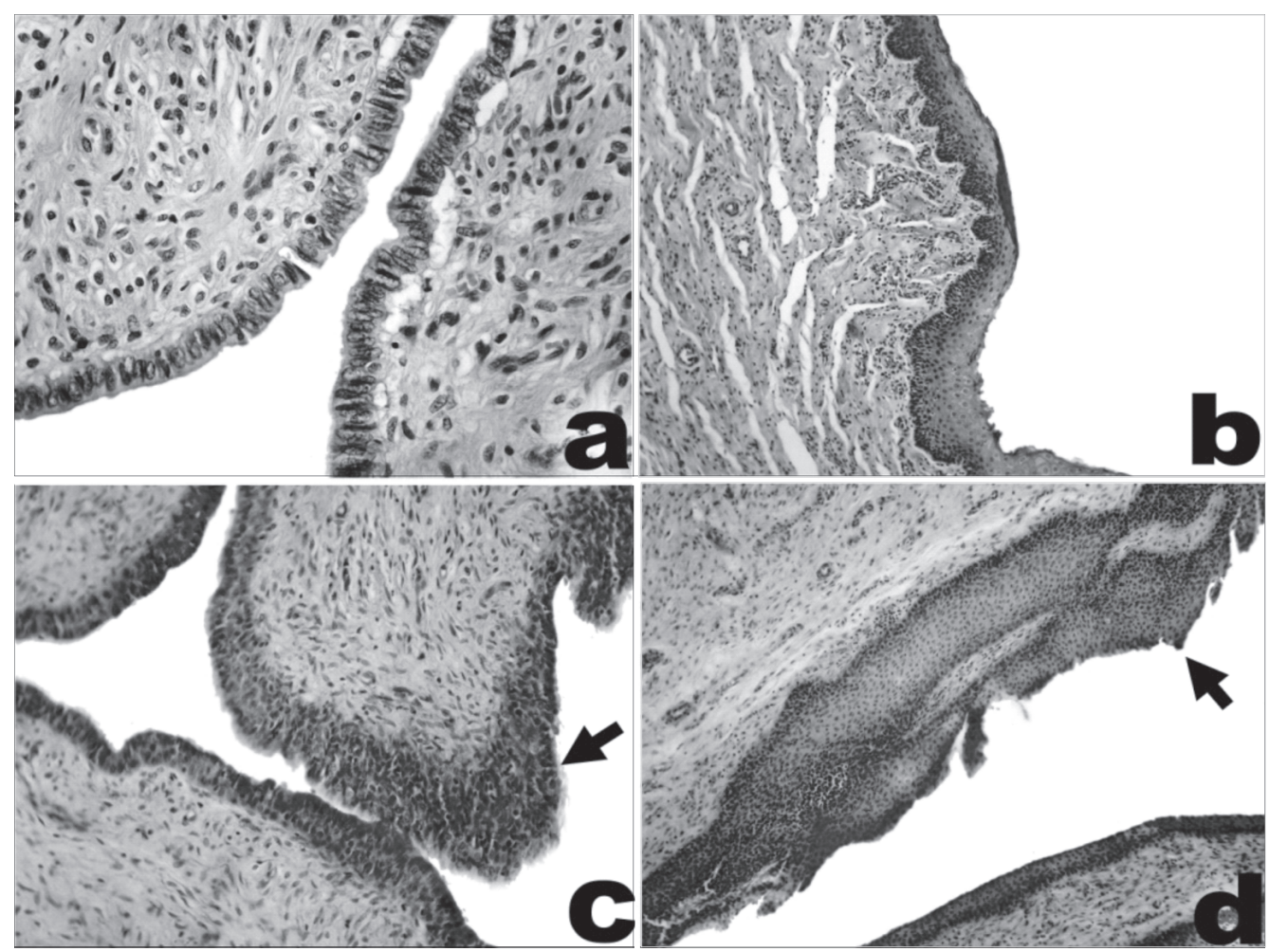

Fig.5. Vaginal canal of gilts, HE. T1 (A and B, control) and T2 (C and D, 0.75mg/kg ZEA). Epithelium near cervix (A and C). Epithelium near vulva (B and D). (A) Uniform and regular epithelial cells (x200). (B) Regular stratification (x100). (C) Epithelium with irregular cellular proliferation (arrow) (x100). (D) Irregular stratified epithelium (arrow) (x100). 
Fig.3. The T2 group showed a significantly higher uterine epithelial cells height $(\mathrm{P}<0.05)$.

\section{Morphological and histopathologic analysis of the organs}

No macroscopic changes were observed in the examined organs, except in two animals of T2 which had cystic ovaries.

On histopathologic evaluation, from both treatments, the mesenteric lymph nodes were within normal characteristics. There was mild biliary hyperplasia in samples of liver in T1 and T2. The histologic analysis of the reproductive tract showed proliferation (hyperplasia) of the epithelial cell layer of the uterine (Fig.4) and vaginal mucosa (Fig 5), resulting in thickening and irregularity of the epithelium from gilts of T2 group. Squamous metaplasia in uterus and hyperplasia of the endometrial glands (Fig.4) were also observed.

\section{Weight gain}

No differences were observed between the mean total weight gain (11.96 and $12.59 \mathrm{~kg}$ ) of T1 and T2 groups $(\mathrm{P}>0.05)$.

\section{Hematological and biochemical analysis and humoral immune response against SRBC}

There were no significant differences between treatments for hematologic and serum biochemistry analysis and in the titers for immunization with SRBC.

\section{DISCUSSION}

Mycotoxicological analysis results suggest frequent occurrence of ZEA in Brazilian grains (Salay \& Mercadante 2002), since this mycotoxin was found in the regular corn and soybean meal used in this experiment.

The measurement of vulvar area demonstrated a significant difference only in the $21^{\text {st }}$ day of ZEA exposure. This result differs from that obtained by Andretta et al. (2008), who used $2 \mathrm{mg} / \mathrm{kg}$ and observed increase of the vulva (vulvar volume) already in the first week of exposure of prepubertal females to ZEA. The differences in dose and time of exposure between studies reinforce the importance of these variables in the manifestation of clinical signs, especially when edema and hyperemia of the vulva are seen.

The parameter of the vulvar area showed a great variation, although significant differences between treatments were observed. Therefore, for experimental tests with low concentrations of ZEA, this parameter is not ideal for evaluation. It is also important to note that the presence of ZEA in the control group may have influenced the wide variation of this parameter, and possibly underestimated the effects produced by ZEA especially in the reproductive tract.

Measurements of epithelial cells height demonstrate the ability of ZEA to cause hypertrophy of uterine cells in rats (Heneweer et al. 2007). In the present study, prolonged exposure to lower concentrations of ZEA also resulted in these findings. On the other hand, Doll et al. (2004) found no increase in height of uterus epithelial cells and endometrial glands despite having observed increase in uterus weight in the group with $0.42 \mathrm{mg} / \mathrm{kg}$, this result may have occurred because there was an association of ZEA and deoxynivalenol (DON). DON reduces protein synthesis in the cell and in this case it may have suppressed the effects of ZEA (Doll et al. 2004, Feinberg \& McLaughlin 1989).

Several studies with ZEA intoxication have shown hyperplasia of the uterine and vaginal mucosa (Bristol \& Djurickovic 1971, Chang et al. 1979, Etienne \& Dourmad 1994, Fink-Grem-mels \& Malekinejad 2007) as well as of the endometrial glands (Speranda et al. 2006, Ványi et al. 1994), as seen in this study. The presence of cysts in the ovaries of group T2 indicated maturation of ovarian follicles caused by the mycotoxin (Ványi et al. 1994).

Signs of hyperestrogenism occurred in this experiment with lower doses of ZEA compared to other studies, which respectively used doses of $2 \mathrm{mg} / \mathrm{kg}$ (Andretta et al. 2008) and higher than 3mg/kg (Etienne \& Jemmali et al. 1982), respectively. In dose-response investigation with incremental concentrations of ZEA, Doll et al. (2003) observed increased weight of uterus at low concentrations $(0.42 \mathrm{mg} / \mathrm{kg})$.

Knowledge of the limit levels of ZEA capable of producing toxic effects is important for the establishment of laws with acceptable limits of this mycotoxin in swine diets, especially in Brazil where these limits are not determined yet. The concentrations of ZEA are controlled in feed and food of 16 countries since 2003 (FAO 2004). The EU regulation for instance allows concentrations of ZEA at 0.1 and $0.3 \mathrm{mg} / \mathrm{kg}$ for prepubertal gilts and mature sows, respectively (EC 2006).

ZEA acts by stimulating protein synthesis inducing uterine cell proliferation and increasing the mass of the reproductive organs (Gaumy et al. 2001), so the results of this study showing increase of the reproductive tract weight, vulvar area and epithelial cell hypertrofia and hyperplasia of the uterine and vaginal mucosa as well as endometrial glands, show their potential estrogenic at concentration of $0.75 \mathrm{mg} / \mathrm{kg}$. In mammals, two nuclear receptors mediate the actions by stimulating the binding of estrogen, the $\alpha$ - and $\beta$-estrogen receptors, having the predominance of $\alpha$-estrogen receptors in the uterus (Klinge 2001, Nilsson et al. 2001, Wang et al. 1999). This also reflects in higher affinity of the metabolite $\alpha$-zearalenol to bind estrogen receptors (Takemura et al. 2007) and greater susceptibility of pigs to the effects of ZEA by the predominance in the production of this metabolite (Malekinejad et al. 2006).

There were no differences in weight gain between groups. In other studies, even with ingestion of equal and greater amounts ZEA, as high as $2 \mathrm{mg} / \mathrm{kg}$, there were no changes in animal performance (Speranda et al. 2006, Andretta et al. 2008). This reinforces the action of ZEA mainly in the reproductive tract, without changing the zootechnical performance parameters significantly.

The presence of mild hyperplasia of bile ducts in both treatments may be related to the fact that in T1 ZEA concentration was of $0.335 \mathrm{mg} / \mathrm{kg}$. ZEA metabolism in the liver may also be indicative of response to mild toxicity. In addition, the presence of aflatoxin in milled corn, even if in low concentration, or the presence of other mycotoxins and toxic agents in the diet that were not surveyed, may cause higher metabolic activity in this organ, including in the group that did not receive additional ZEA, just what was already present in the corn and soybean (T1).

There were no significant differences in blood hematolo- 
gical and biochemical parameters between treatments. In gilts exposed to $3 \mathrm{mg} / \mathrm{kg}$ of ZEA the levels of increase of AST, GGT and lactate dehydrogenase were increased (Speranda et al. 2006). The influence of this intoxication on these parameters are poorly described in the literature for pigs; however, there are studies demonstrating hematotoxic and hepatotoxic actions of ZEA in rats and mice (Maaroufi et al. 1996, Abbés et al. 2006, Stadnik et al. 2009).

The evaluation of SRBC antibody titers was used extensively in the literature (Peplowski et al. 1980, Bonnette et al. 1990, Rotter et al. 1994) to study the immune response of animals. It is known; however, that the immune response to different challenges is extremely complex. In the challenge with sheep erythrocytes, Rotter et al. (1994) also found no significant difference, but a numerically delayed response of antibody titers of piglets with 5-6 weeks of age fed with low concentrations of DON $(0,0.75,1.5,3 \mathrm{mg} / \mathrm{kg})$ and ZEA $(0$, $0.05,0.08,0.15 \mathrm{mg} / \mathrm{kg}$ ) was observed.

No histologic changes was observed in lymph nodes, there was no lymphoid depletion, however, mycotoxins can affect immune responses of animals in different ways, from changes in the production of enzymes and cytokines to an increased production of free radicals that indirectly affect these parameters (Surai \& Dvorska et al. 2005). Other studies report inhibitory effects of ZEA on the proliferation of lymphocytes, demonstrating its immunotoxic potential at high concentrations. Abbés et al. (2006) observed significant reduction in the number of lymphocytes T cells CD3+, CD4+, CD8+ and CD56+ in mice with $40 \mathrm{mg} / \mathrm{kg}$ of ZEA. Luongo et al. (2008), in an in vitro study, with low concentrations $(2.5 \mu \mathrm{m})$ of ázearalenol observed inhibitory effect on cell proliferation of pig lymphocytes. It is believed that this methodology may not have been able to determine the real effect of ZEA on immune response.

The concentration of $0.75 \mathrm{mg} / \mathrm{kg}$ of ZEA was sufficient to produce the effect of increasing reproductive tract weight, vulvar area, and causing hypertrofia and hyperplasia of the epithelial cells of the endometrial glands and superficial cells of uterine mucosa as well as vaginal mucosa. Furthermore, no changes on animal body weight gain, hematologic parameters, serum biochemistry analysis and finally, humoral immune response against sheep red blood cells were observed in this investigation.

Acknowledgments.- To Professor Edson Moleta Colodel, from Federal University of Mato Grosso, for his help in the histopathologic analyses. Additionally, we would like to thank Pedro Celso Machado Junior and Marcel Louis Joineau's (Impextraco ${ }^{\circledR}$, Curitiba-PR, Brazil) for help and financial support.

\section{REFERENCES}

Abbès S., Salah-Abbès J.B., Ouanes Z., Houas Z., Othman O., Bacha H., AbdelWahhab M.A. \& Oueslati R. 2006. Preventive role of phyllosilicate clay on the Immunological and Biochemical toxicity of zearalenone in Balb/c mice. Int.Immunopharmacol. 6:1251-1258. doi:10.1016/j.intimp. 2006.03.012.

Andretta I., Lovatto P.A., Hauschild L., Dilkin P., Garcia G.G., Lanferdini E., Cavazini N.C. \& Mallmann C.A. 2008. Alimentação de leitoas pré-púberes com dietas contendo ZEA. Arq. Bras. Med. Vet. Zootec. 60(5):1227-1233.

Bonnette E.D., Kornegay E.T., Lindemann M.D. \& Hammerberg C.1990. Humoral and cell-mediated immune response and performance of weaned pigs fed four supplemental vitamin E levels and housed at two nursery temperatures. J. Anim. Sci. 68:1337-1345.

Bristol F.M. \& Djurickovic S. 1971. Hyperestrogenism in female swine as the result of feeding mouldy corn. Can. Vet. J. 12(6):132-135.

Chang K., Kurtz H.J. \& Mirocha C.J. 1970. Effects of the mycotoxin zearalenone on swine reproduction. Am. J. Vet. Res. 40:1260-1267.

Cheng Y-H., Weng C-F., Chen B.-J. \& Chang M.-H. 2006. Toxicity of different Fusarium mycotoxins on growth performance, immune responses and efficacy of a mycotoxin degrading enzyme in pigs. Anim. Res. 55:579590. doi: 10.1051/animres:2006032.

Doll S., Danicke S., Ueberscha K.-H., Valenta H., Chnurrbusch U., Ganter M., Klobasa F. \& Flachowsky G. 2003. Effects of graded levels of Fusarium toxin contaminated maize in diets for female weaned piglets. Archs Anim. Nutr. 57:311-334. doi: 10.1080/00039420310001607680.

Doll S., Danicke S. \& Schnurrbusch U. 2004. The effect of increasing concentrations of Fusarium toxins in piglet diets on histological parameters of the uterus and vagina. Archs Anim. Nutr. 58:413-417. doi:10.1080/ 00039420400004987.

European commission. 2006. Commission recommendation of 17 August 2006 on the presence of deoxynivalenol, zearalenone, ochratoxin, T-2 and HT-2 and fumonisin in products intended for animal feeding. Off. J. Eur. Union L 229:7-9.

Etienne M. \& Jemmali M. 1982. Effects of zearalenone (F2) on estrous activity and reproduction in gilts. J. Anim. Sci. 55:1-10.

Etienne M. \& Dourmad J.Y. 1994. Effects of zearalenone or glucosinolates in the diet on reproduction in sows: A review. Livest. Prod. Sci. 44:99-113.

FAO 2004. Worldwide regulations for mycotoxins in food and feed in 2003. FAO Food and Nutrition paper nr. 81. Food and Agriculture Organization of the United Nations, Rome, Italy.

Feinberg B. \& McLaughlin C.S. 1989. Biochemical mechanism of action of trichothecene mycotoxins, p.27-35. In: Beasley V.R. (Ed.), Trichothecene Mycotoxicosis: Pathophysiological effects. Florida.

Fink-Gremmels J. \& Malekinejad H. 2007. Review: Clinical effects and biochemical mechanisms associated with exposure to the mycoestrogen zearalenone. Anim. Feed Sci. Technol. 137:326-341. doi:10.1016/ j.anifeedsci.2007.06.008.

Gaumy J.L., Bailly J.D., Burgat V. \& Guerre P.2001. Zéaralénone: propriétés et toxicité expérimentale. Revue Méd. Vét. 152(3):219-234.

Heneweer M., Houtman H., Poortman J., Groot M., Maliepaard C. \& Peijnenburg A. 2007. Estrogenic effects in the immature rat uterus after dietary exposure to ethinylestradiol and zearalenone using a systems biology approach. Toxicol. Sci. 99(1):303-31. doi:10.1093/toxsci/kfm151.

Klinge C.M. 2001. Estrogen receptor interaction with estrogen response elements. Nucleic Acids Res. 29(14):2905-2919.

Kumar V., Basu M.S. \& Rajendran T.P. 2008. Mycotoxin research and mycoora in some commercially important agricultural commodities. Crop Protection 27:891-905. doi:10.1016/j.cropro.2007.12.011.

Kuiper-Goodman T., Scott P.M., \& Watanabe H. 1987. Risk assessment of the mycotoxin zearalenone. Regul. Toxicol. Pharmacol. 7(3):253-306.

Luongo D., De Luna R., Russo R. \& Severino L. 2008. Effects of four Fusarium toxins (fumonisin B1, $\alpha$-zearalenol, nivalenol and deoxynivalenol) on porcine whole-blood cellular proliferation. Toxicon 52:156-162. doi:10.1016/j.toxicon.2008.04.162.

Maaroufi K., Chekir L., Creppy E.E., Ellouz F. \& Bacha H. 1996. Zearalenone induces modications in haematological and biochemical parameters in rats. Toxicon 34(5):534-540.

Malekinejad H., Maas-Bakker R. \& Fink-Gremmels J. 2006. Species differences in the hepatic biotransformation of zearalenone. Vet. Journal 172:96-102. doi:10.1016/j.tvjl.2005.03.004.

Martins L.M. \& Martins H.M. 2002. Inuence of water activity, temperature and incubation time on the simultaneous production of deoxynivalenol and zearalenone in corn (Zea mays) by Fusarium graminearum. Food Chemistry 79:315-318.

Mostrom M.S. 2007. Zearalenone, p.977-982. In. Gupta R.C. (Ed.), Veterinary Toxicology: Basic and clinic principles. Academic Press, New York. 
Nilsson S., Makela S., Treuter E., Tujague M., Thomsen J., Andersson G., Enmark E., Pettersson K., Warner M. \& Gustafsson J.A. 2001. Mechanisms of estrogen action. Physiol. Rev. 81(4):1535-1565

NRC 1998. Nutrient Requirements of Swine. National Academy of Science, Washington, DC.

Olsen M., Pettersson H. \& Kiessling K.H. 1981. Reduction of zearalenone to zearalenol in female rat liver by 3 alpha-hydroxysteroid dehydrogenase. Acta Pharmacol. Toxicol. 48(2):157-161

Peplowski M.A., Mahan D.C., Murray F.A., Moxon A.L., Cantor A.H. \& Ekstrom K.E. 1980. Effect of dietary and injectable vitamin e and selenium in weanling swine antigenically challenged with sheep red blood cells. J. Anim. Sci. 51:344-351

Rotter B.A., Thompson B.K., Lessard M., Trenholm H.L. \& Tryphonas H. 1994. Influence of low-level exposure to Fusarium mycotoxins on selected immunological and hematological parameters in young swine. Fundamental and Applied Toxicology 23:117-124

Salay E. \& Mercadante A.Z.2002. Mycotoxins in Brazilian corn for animal feed: Occurrence and incentives for the private sector to control the level of contamination. Food Control 13:87-92.

Schurig G.G., Duncan J.R. \& Winter A.J. 1978. Elimination of genital vibriosis in female cattle by systemic immunization with killed cells or cell-free extracts of Campylobacter fetus. J. Infect. Dis. 138(4):463-472.

Smith T.K., Diaz G. \& Swamy H.V.L.N. 2005. Current concepts in micotoxicoses in swine, p.235-247. In: Diaz D.E. (Ed.), The Mycotoxin Blue Book. Nottingham, UK.
Speranda M., Liker B., Speranda T., Seric V., Antunovic Z., Grabarevic Z., Sensic D., Grguric D. \& Steiner Z. 2006. Haematological and biochemical parameters of weaned piglets fed on fodder mixture contaminated by zearalenone with addition of clinoptilolite. Acta Vet., Beograd, 56(2/3):121-136.

Surai P.F. \& Dvorska J.E. 2005. Effects of mycotoxins on antioxidant status and immunity, p.93-137. In: Diaz D.E. (Ed.), The Mycotoxin Blue Book. Nottingham, UK.

Stadnik A. \& Borzêcki A. 2009. Influence of the zearalenone on the activity of chosen liver enzymes in a rat. Ann. Agric. Environ. Med. 16:31-35.

Takemura H., Shim J., Sayama K., Tsubura A., Zhu B. \& Shimoi K. 2007. Characterization of the estrogenic activities of zearalenone and zeranol in vivo and in vitro. J. Steroid Biochem. Molecul. Biol. 103:170-177. doi:10.1016/j.jsbmb.2006.08.008

Ványi A., Bata A., Glávits R. \& Kovács F. 1994. Perinatal oestrogen syndrome in swine. Acta Vet. Hung. 42:433-46.

Vargas E.A., Preis R.A., Castro L. \& Silva C.M. 2001. Co-occurrence of aflatoxins B1, B2, G1, G2, zearalenone and fumonisin B1 in Brazilian corn. Food Addit. Contam. 18:981-986.

Zinedine A., Soriano J.M., Molto J.C. \& Mañes J. 2007. Review on the toxicity, occurrence, metabolism, detoxification, regulations and intake of zearalenone: An oestrogenic mycotoxin. Food Chem. Toxicol. 45:1-18. doi:10.1016/j.fct.2006.07.030

Wang H., Masironi B., Eriksson H. \& Sahlin L. 1999. A comparative study of estrogen receptors \{alpha\} and $\{$ beta\} in the rat uterus. Biol. Reprod. 61(4):955-964. doi:10.1095/ biolreprod61.4.955 